\title{
Anti-hypertensive therapy with propranolol during pregnancy and lactation
}

\author{
E. A. TAYLOR \\ B.Pharm., Ph.D. \\ P. TURNER \\ M.D., B.Sc., F.R.C.P.

\begin{abstract}
Department of Clinical Pharmacology, St Bartholomew's Hospital Medical College,
\end{abstract} \\ West Smithfield, London EC1A $7 B E$
}

\begin{abstract}
Summary
A hypertensive woman was treated throughout pregnancy with propranolol $40 \mathrm{mg}$ daily without complication. At delivery the umbilical cord plasma concentration was similar to that in the maternal venous plasma. Milk:plasma ratios were less than 1, although a higher ratio would be predicted. Estimated daily intake of propranolol in breast milk by the infant was about $3 \mu \mathrm{g}$. There appears to be no reason to advise women receiving propranolol to avoid breast feeding.
\end{abstract}

\section{Introduction}

Propranolol has been administered to patients with a variety of conditions associated with pregnancy such as: hypertension (Tcherdakoff et al., 1978; Eliahou et al., 1978), hyperthyroidism (Bullock, Harris and Young, 1975; Burrow, 1978), cardiac arrhythmias (Schroeder and Harrison, 1971; Levitan and Manion, 1973), hypertrophic obstructive cardiomyopathy (Turner, Oakley and Dixon, 1968; Datta et al., 1978) and fetal tachycardia in diabetic pregnancy (Teuscher et al., 1978).

Its use has been questioned for 2 main reasons: its possible stimulant action on uterine muscle due to $\beta^{2}$-adrenoceptor blockade (Pose, Cibils and Zuspan, 1962; Wansbrough, Nakanishi and Wood, 1968) and its pharmacological effects on the fetus (Habib and McCarthy, 1977; Cottrill et al., 1977). The main effects seen in the neonate are low birthweight (Reed et al., 1974; Oakley et al., 1979) possibly owing to inadequate perfusion of the fetal side of the placenta (Barden and Stander, 1968), hypoglycaemia and bradycardia (Habib and McCarthy, 1977; Cottrill et al., 1977), and respiratory depression (Tunstall, 1969). However, other workers have given $\beta$-adrenoceptor antagonists to pregnant women with no ill effects on mother or child (Tcherdakoff et al., 1978; Gallery et al., 1978; Dubois et al., 1978). Gallery et al. (1978) found a significant inverse relationship between blood pressure in untreated hypertensive subjects in late pregnancy, and birthweight which was reversed in 19 patients treated with oxprenolol. In 3 patients, side effects of propranolol were seen with daily doses greater than $160 \mathrm{mg}$ (Cottrill et al., 1977; Gladstone, Hordof and Gersony, 1975); however, they are also seen, less frequently, with lower daily doses (Habib and McCarthy, 1977).

Cottrill et al. (1977) observed in the neonate an increase in the plasma propranolol concentration from about $30 \mathrm{ng} / \mathrm{ml}$ at birth to $90 \mathrm{ng} / \mathrm{ml}$ by $4 \mathrm{hr}$. Their suggestion that this could be due to a redistribution of the drug, perhaps in combination with defective elimination, was interesting and worth further investigation.

\section{Case report}

The authors have studied a hypertensive patient who took propranolol $20 \mathrm{mg}$ twice daily throughout pregnancy. At delivery, samples of maternal venous and umbilical cord blood were taken for the measurement of propranolol concentrations in plasma. Neonatal venous plasma concentrations of propranolol were followed for $4 \mathrm{hr}$ after birth, and the progress of the neonate during the first week after birth was recorded.

A 28 -year-old patient, gravida 1, para 0 , who had regularly attended the hypertension clinic at St Bartholomew's Hospital before pregnancy, continued on oral propranolol throughout pregnancy. Her blood pressure at the last visit to the clinic at 39 weeks was $115 / 85 \mathrm{mmHg}$. After admission to hospital the patient was taking, in addition to propranolol, mefenamic acid (Ponstan) capsules $250 \mathrm{mg}$ - one or 2 daily; magnesium trisilicate mixture $10 \mathrm{ml} / 2 \mathrm{hr}$; nitrazepam $5 \mathrm{mg}$ - one at night; dextropropoxyphene $32.5 \mathrm{mg}$ and paracetamol $325 \mathrm{mg}$ (Distalgesic) - one or $2 / 6 \mathrm{hr}$ (after delivery); ferrous sulphate and folic acid (Fe Folic) - one daily.

The last dose of propranolol was given $3.15 \mathrm{hr}$ before delivery. At $00 \cdot 15 \mathrm{hr}$ (day 1) the patient underwent a spontaneous vaginal delivery of a $3420 \mathrm{~g}$ female with Apgar scores of 8 at one min and 9 at $5 \mathrm{~min}$. At delivery the maternal blood pressure was $125 / 80 \mathrm{mmHg}$, and at this time a $10-\mathrm{ml}$ sample of 
venous blood from the mother and a $10-\mathrm{ml}$ bood sample from the maternal end of the umbilical cord were taken into lithium-heparin. Four blood samples of approximately $2 \mathrm{ml}$ each were collected from the neonate at $0 \cdot 5,1,2$ and $4 \mathrm{hr}$ after delivery, the $0 \cdot 5-\mathrm{hr}$ sample through a small butterfly cannula in the antecubital vein and subsequent samples by heel prick. Plasma was separated and stored at $-20^{\circ} \mathrm{C}$ until assayed by gas-liquid chromatography (McAinsh et al., 1978). The lower limit of sensitivity of the method was a concentration in plasma of $8 \mathrm{ng} / \mathrm{ml}$. The results are given in Table 1 .

The patient was reluctant to give more blood, but it was possible to obtain 2 more specimens of breast milk at different times after dosing to estimate how much propranolol the infant was receiving per day. All samples were taken at the end of feeding. The blood samples were treated as above and the concentrations of propranolol in plasma and in whole milk were measured by the method described by McAinsh et al. (1978). The lower limit of sensitivity of the assay in milk was $2 \mathrm{ng} / \mathrm{ml}$. The results are also shown in Table 1.

For the estimation of the daily intake of drug by the neonate, both the concentration of propranolol in milk and the volume of milk taken per day must be known. The infant was therefore weighed before and after each feed over a 24-hr period. Assuming a mean concentration of $10 \mathrm{ng} / \mathrm{ml}$ in milk, the intake of propranolol by the neonate on the fifth day after birth was estimated to be approximately $3 \mu \mathrm{g}$.

The apex heart rate of the infant receiving propranolol was compared to that in one female and 2 male infants of similar ages and weights at 6 p.m. and 6 a.m. on days 4 and 5 respectively, and with 5 other female infants of similar ages and weights at the same times on days 6 and 7 . There was no difference between the heart rate of the infant receiving propranolol and that of the other infants over the period of investigation. The heart rate of the infant receiving propranolol was 136 and 144 beats/min on days 4 and 5 respectively, and the mean \pm s.d. of the control infants was $120 \cdot 7 \pm 3 \cdot \frac{1}{.}$ and $133.3 \pm 9.9$ at the same times. On days 6 and the heart rate of the baby being investigated was? 136 and 140 beats/min respectively, and the mear of the control infants was $140 \cdot 0 \pm 7 \cdot 6$ and $140 \cdot 0 \pm 8 \cdot 9$ 은

\section{Discussion}

In this patient treated with a low dose of proprano\% lol throughout pregnancy, there were no detectable: adverse effects on mother or infant. This is consistent with the view that in patients with hypertension, ind the absence of other complictions, taking $<16 \Phi$ $\mathrm{mg} /$ day of propranolol, few maternal or neonata adverse effects are seen (Tcherdakoff et al., 1978 $\frac{\mathrm{Z}}{\mathrm{s}}$. Gregoric et al., 1978).

There is no doubt that propranolol crosses the placenta, as plasma concentrations have beeng reported in several neonates (Habib and McCarthy苻 1977; Cottrill et al., 1977; Langer et al., 1974:Teuscher et al., 1978). Information on the phara macokinetics of drugs in the newborn is scant and often restricted to single determinations of drug concentrations in maternal and neonatal blood samples at delivery. Langer et al., (1974) and Teuscher et al. (1978) found that the propranowot concentration in neonatal blood and plasma yga one fifth of the maternal concentration at deliver and also $2.5 \mathrm{hr}$ later in the case of the latter workers A slightly higher concentration in umbilical corf plasma (arterial and venous) than in maternal plasm墕 was reported by Cottrill et al. (1977) which is similar to the present results. Teuscher et al. (1978 found that the plasma drug concentration in the neonate fell from $26 \mathrm{ng} / \mathrm{ml}$ at delivery to $18.5 \mathrm{ng} / \mathrm{m}$. $2.5 \mathrm{hr}$ later. This decline was similar to that in the present study where the neonatal plasma concen 3 . tration fell from $14 \mathrm{ng} / \mathrm{ml}$ at birth to $11 \mathrm{ng} / \mathrm{ml} \mathrm{byog}$ $0.5 \mathrm{hr}$, and to less than $8 \mathrm{ng} / \mathrm{ml}$ by one $\mathrm{hr}$.

TABLE 1. Plasma concentration of propranolol in mother and umbilical cord at time of delivery, and in the neonate $0.5,1,2$ and $4 \mathrm{hr}$ after birth. Propranolol concentration in breast milk and simultaneous samples of maternal blood are shown

\begin{tabular}{cccccc}
\hline $\begin{array}{c}\text { Day sample } \\
\text { taken }\end{array}$ & $\begin{array}{c}\text { Time after last } \\
\text { dose (hr) }\end{array}$ & Mother & Plasma Cord & Infant & Milk \\
\hline 1 & $3 \cdot 25$ & 19 & 14 & & \\
1 & $3 \cdot 75$ & & & ND (1 hr) & \\
1 & $4 \cdot 25$ & & ND (2 hr) & \\
1 & $5 \cdot 25$ & & ND (4 hr) & 20 \\
1 & $7 \cdot 35$ & $1-2$ & & & 4 \\
3 & $2 \cdot 25$ & 17 & & ND \\
4 & 12 & & & 11 \\
5 & $3 \cdot 25$ & 16 & & & \\
\hline
\end{tabular}

$\mathrm{ND}=$ below the limit of detection $-8 \mathrm{ng} / \mathrm{ml}$ for plasma, $2 \mathrm{ng} / \mathrm{ml}$ for milk. 
In the present study, the concentration ratio of propranolol in milk to that in plasma was $0 \cdot 24,2 \cdot 25$ $\mathrm{hr}$ after the last dose, and $0.69,3.25 \mathrm{hr}$ after the last dose of propranolol. These ratios were similar to those reported by Bauer et al. (1979) and Levitan and Manion (1973). Karlberg, Lundberg and Aberg (1974) found milk : plasma ratios of propranolol concentration of approximately 1 after various single oral doses in 2 nursing mothers. Human milk is at pH 6.5 to 7.0; therefore, for a weak base such as propranolol ( $\mathrm{pKa} 9 \cdot 45$ ), a milk - plasma ratio $>1$ would be expected, binding to protein and lipids in milk would be expected further to increase the ratio. Karlberg et al. (1974) suggested that the lower ratios usually seen may be a result of propranolol in milk equilibrating with that free in plasma during the time of increasing plasma concentrations, i.e. during the time interval preceding peak plasma concentrations when most blood samples were taken. However, propranolol is such a lipid-soluble drug that equilibrium across a lipid membrane would be expected to occur rapidly. Furthermore, in a patient taking propranolol $40 \mathrm{mg} 4$ times daily, both plasma and milk concentrations were found to peak at $3 \mathrm{hr}$ after the last dose of drug, and both declined thereafter (Bauer et al., 1979). It is, therefore not known why the milk : plasma ratio of propranolol concentration is $<1$.

The estimated intake of propranolol was $3 \mu \mathrm{g}$ daily by the infant in the present study. Bauer et al. (1979) estimated, using the peak propranolol concentration after dosage at $160 \mathrm{mg}$ daily $(42 \mathrm{ng} / \mathrm{ml}$ of propranolol in breast milk) and assuming that the infant's total ingestion will not exceed $500 \mathrm{ml} / \mathrm{day}$, the maximum cumulative propranolol intake would be $21 \mu \mathrm{g}$ in $24 \mathrm{hr}$. After $240 \mathrm{mg}$ daily for 30 days $(64 \mathrm{ng} / \mathrm{ml}$ propranolol in milk), the maximum cumulative propranolol intake would be $32 \mu \mathrm{g}$ in $24 \mathrm{hr}$.

There appears to be no basis for the statement by Ananth (1978) that 'under no circumstances should this drug be administered to a nursing mother, and no mother taking this medication should be permitted to breast-feed her infant'.

\section{Acknowledgments}

We thank Dr J. McAinsh of the Pharmacokinetic Section, Safety of Medicines Department, I.C.I. Ltd, for arranging the assay of the samples in this study, and the nurses on the neonatal unit at St Bartholomew's Hospital, for their help.

\section{References}

ANANTH, J. (1978) Side effects in the neonate from psychotropic agents excreted through breast-feeding. American Journal of Psychiatry, 135, 801.

BARDEN, T.P. \& STANDER, R.W. (1968) Effects of adrenergic blocking agents and catecholamines in human pregnancy. American Journal of Obstetrics and Gynecology, 102, 226.

BaUer, J.H., PaPe, B., ZaJicek, J. \& Groshong, T. (1979)
Propranolol in human plasma and breast milk. American Journal of Cardiology, 43, 860.

Bullock, J.L., HARRIS, R.E. \& Young, R. (1975) Treatment of thyrotoxicosis during pregnancy with propranolol. American Journal of Obstetrics and Gynecology, 121, 242.

BURROw, G.N. (1978) Hyperthyroidism during pregnancy. New England Journal of Medicine, 298, 150.

Cottrill, C.M., McAllister, R.G., Gettes, L. \& Noonan, J.A. (1977) Propranolol therapy during pregnancy, labor, and delivery: evidence for transplacental drug transfer and impaired neonatal drug disposition. Journal of Pediatrics. St Louis, 91, 812.

Datta, S., Kitzmiller, J.L., Ostheimer, G.W. \& SchoenBAUM, S.C. (1978) Propranolol and parturition. Obstetrics and Gynecology, 51, 557.

Dubois, D., Temperville, B., Petitcolas, J. \& Klepper, A.K. (1978) Bêta-bloquants au cours des grossesses à haut risques. Nouvelle Presse Médicale, 7, 3769.

Eliahou, H.E., Silverberg, D.S., Reisin, E., Romem, I., MAShiach, S. \& SERR, D.M. (1978) Propranolol for the treatment of hypertension in pregnancy. British Journal of Obstetrics and Gynaecology, 85, 431 .

Gallery, E.D.M., SAunders, D.M., HunYor, S.N. \& GYÖRY, A.Z. (1978) Improvement in foetal growth with treatment of maternal hypertension in pregnancy. Clinical Science and Molecular Medicine, 55 (Suppl. 4), 359S.

Gladstone, G.R., Hordof, A. \& Gersony, W.M. (1975) Propranolol administration during pregnancy: effects on the fetus. Journal of Pediatrics, 86, 962.

Gregoric, G., Majstorovic, B., Najdanovic, B. \& Popovic, A. (1978) Clinical experience with propranolol in treatment of hypertension in pregnancy. Proceedings of the VIIIth World Congress on Cardiology, Tokyo, abstr. 1035616. $117 \mathrm{CA}$.

HABIB, A. \& MCCARTHY, J.S. (1977) Effects on the neonate of propranolol administered during pregnancy. Journal of Pediatrics, 91, 808.

KARLBERG, B., LuNDBerg, D. \& ÅberG, H. (1974) Excretion of propranolol in human breast milk. Acta pharmacologica toxicologica, 34, 222.

Langer, A., Hung, C.T., McA'Nulty, J.A., Harrigan, J.T. \& Washington, E. (1974) Adrenergic blockade. A new approach to hyperthyroidism during pregnancy. Obstetrics and Gynecology, 44, 181.

Levitan, A.A. \& Manion, J.C. (1973) Propranolol therapy during pregnancy and lactation. American Journal of Cardiology, 32, 247.

McAInsh, J., BAber, N.S., Smith, R. \& Young, J. (1978) Pharmacokinetic and pharmacodynamic studies with long-acting propranolol. British Journal of Clinical Pharmacology, 6, 115.

OAKLeY, G.D.G., McGarRy, K., Limb, D.G. \& OAKley, C.M. (1979) Management of pregnancy in patients with hypertrophic cardiomyopathy. British Medical Journal, 1, 1749.

Pose, S.V., Cibils, L.A. \& Zuspan, F.P. (1962) Effect of 1-epinephrine infusion on uterine contractility and cardiovascular system. American Journal of Obstetrics and Gynecology, 84, 297.

Reed, R.L., Cheney, C.B., Pearson, R.E., Hook, R. \& HeHRe, F.W. (1974) Propranolol therapy throughout pregnancy: a case report. Anesthesia Digest. Cleveland, 53, 214.

Schroeder, J.S. \& HARRISON, D.C. (1971) Repeated cardioversion during pregnancy: treatment of refractory paroxysmal atrial tachycardia during three successive pregnancies. A:nerican Journal of Cardiology, 27, 445.

TCr:-Rdakoff, P.H., Colliard, M., Berrard, E. \& Kreft, C. (1978) Propranolol in hypertension during pregnancy. British Medical Journal, 2, 670.

Teuscher, A., Bossi, E., ImHof, P., Erb, E., Stocker, F.P. \& 
WEBER, J.W. (1978) Effect of propranolol on fetal tachycardia in diabetic pregnancy. American Journal of Cardio$\log y, 42,304$.

Tunstall, M.E. (1969) The effect of propranolol on the onset of breathing at birth. (abstr.) British Journal of Anaesthesia, 41, 792.

Turner, G.M., OAKLey, C.M. \& Dixon, H.G. (1968) Man- agement of pregnancy complicated by hypertrophic obstructive cardiomyopathy. British Medical Journal, 4 $\overrightarrow{\mathbb{Q}}$ 281.

Wansbrough, H., Nakanishi, H. \& Wood, C. (1968) The effect of adrenergic receptor blocking drugs on the human uterus. Journal of Obstetrics and Gynaecology of the British Commonwealth, 75, 189. 